Article

\title{
Corporate Sustainability and Intangible Resources Binomial: New Proposal on Intangible Resources Recognition and Evaluation
}

\author{
Camelia Oprean-Stan ${ }^{1, *}$, Sebastian Stan ${ }^{2}$ and Vasile Brătian ${ }^{1}$ \\ 1 Department of Finance and Accounting, Lucian Blaga University of Sibiu, 550324 Sibiu, Romania; \\ vasile.bratian@ulbsibiu.ro \\ 2 Department of Management, “Nicolae Balcescu” Land Forces Academy, 550170 Sibiu, Romania; \\ sebastian.stan@armyacademy.ro \\ * Correspondence: camelia.oprean@ulbsibiu.ro
}

Received: 8 April 2020; Accepted: 18 May 2020; Published: 19 May 2020

\begin{abstract}
This study argues that the context in which an organization adopts the principles of corporate sustainability and is guided by a culture of sustainability will determine the development of the components of corporate intangible resources. However, in trying to evaluate the impact of adopting the principles of corporate sustainability on the development of the intangible resources held by a company, we encountered a major problem, namely that there is no consistent and internationally accepted methodology for assessing such resources, despite theorists' and practitioners' efforts to develop intangible measurement techniques. The main research objective of this article is to propose the creation of a simplified model for the assessment of intangible resources, which depends only on publicly available information for each of the components of the model. This model can therefore contribute to the practical implementation of intangible resource management by offering an autonomous and objective instrument that uses only publicly available information, thus facilitating comparisons between organizations.
\end{abstract}

Keywords: sustainability; intangible resources; human capital; innovation capital; relationship capital; structural capital; factorial method

\section{Introduction}

In today's turbulent and complex environment, it is increasingly clear that the process of creating corporate sustainability (CS) and sustainable value must be pursued so that organizations may become and remain effective. Managers try to maximize the value of the organizations they lead. An essential way to achieve this goal is to effectively pool the available resources-tangible and intangible-in the activities of a business, with the aim of gaining a significant market share in order to increase the value of the shareholders and, implicitly, of the organization.

The issue proposed for research is of topical interest, because the subject of corporate sustainability has long been analyzed, and it is a common forum for discussion of organizational decision-making and managerial behavior. Stakeholders are increasingly urging companies to devote more capital to CS initiatives. Big US and European businesses are investing millions of dollars in counselling and research on sustainability [1]. Sustainability has a significant impact on the development and improvement of intangible resources (IR).

Intangible resources are factors that lead to an increase in the value of knowledge-based organizations, but current accounting standards do not recognize the shift from tangible to intangible resources in the assessment of organizations. The effect is that the management is currently faced with major difficulties in assessing this type of resource and investors need to rely more on assumptions 
when they want to determine the value of a company in which they are interested. As a result, new ways to facilitate the process of assessing intangible resources are needed, as we have tried to show in this study.

Sustainability has been an extensively discussed subject both conceptually and empirically in the scientific literature [2-7]. Researchers have shown the significance of sustainability at all possible levels, such as at corporate level [8-14], alongside national and global levels [15-17]. Sustainability is also seen as a fundamental component of the strategies of individuals, organizations, and governments. Within this framework, the way in which we adjust to the norms of a globalized world, the challenges we will face in the future, and the new patterns in technologies and products are all an integral part of sustainable development.

When we refer to business sustainability [18-20], we use different concepts, such as sustainable development, citizenship at a corporate level [21], or corporate social responsibility (CSR). Organizations are required to be sustainable, and it is to their greatest advantage to be so [22].

Under growing global sustainability pressures, companies that innovate in their business models are experiencing increased success and profitability, transforming innovation in business models into a primary source of sustained value development and into a necessary response to "major and unpredictable changes in the business environment, like the increasing importance placed on innovation and knowledge as value-creating attributes ... " [23]. Innovation in business models provides a possible solution to making the necessary change by reconceptualizing a company's mission and value and by rethinking value determinants [24].

The concept of business model innovation has only recently been implemented in other fields of research. Over the last few years, the current debate on business model innovation in relation to sustainability has gained an important place. In the current competitive economic context, business models can help to promote the sustainability of a company through its value-creation mechanisms [25]. Studies have examined the variables and business model designs that can help businesses to obtain triple results-social, environmental, and financial [23,26-28].

With careful redesign of a business model, companies can more easily integrate sustainability into their business. Innovations in a business model need to focus on optimizing the benefits of society and the environment rather than just economic gain [23].

The concept of sustainable value creation [29-31] provides new thinking frameworks in order to expand value. The main aim of an organization is to develop and increase performance [32,33]. Intangible resources are at the center of this evolution, as they represent the key value of making resources that should be created and used effectively to develop and maximize corporate value. Innovation related to a business model is central to a firm's success, and intangibles become positive moderators [34].

The importance of intellectual capital (IC) (broadly, intangible resources) is one of the most investigated subjects available in the current scientific literature addressing the development of societies and organizations [35-41]. Due to the growing importance of the knowledge-based economy, intangible resources have become a vector for improving profitability [42], sustainable growth and value [43], competitiveness, and the sustainability of companies [22,42,44-47]. Intellectual capital (IC) is a fundamental driver of performance. It has the power to create and maintain sustainability and competitive advantage in every business $[37,48]$.

The first question that organizations face when they want to implement an intangible resource management system is the following: "What are the elements that constitute intangible resources?" Splitting these intangibles into distinct elements will allow managers to make effective decisions [49]. To date, the most popular structure of intangible elements-with three elements (human, relational, and structural)—was proposed in 1994 by Sveiby and Edvinsson [50]. This structure has also been reported by Stewart [51].

Once the elements that constitute intangible resources have been identified, the following question may be asked: "How are these elements measured?" Intangible resources can be considered as a gray 
area for businesses because they are difficult to evaluate, but they have properties that have a decisive influence on the development of an organization [52,53].

It has been noted lately that there has been an increase in the efforts by theorists and practitioners to develop practical tools for measuring intangible resources. Since the 1990s, intangible resources have been evaluated using a number of direct measurement methods (e.g., the Technology Broker method and citation-weighted patents); techniques depending on the return on assets and on economic value added (EVA); score-based methods (e.g., the Skandia Navigator method, the Knowledge Capital Scoreboard method); and methods based on stock market capitalization and mathematical methods.

Confusion around the concept and components of intangible resources at the organizational level and around related concepts (such as intellectual property or capital, intangible or intellectual assets, information or knowledge assets, etc.) is a major part of the problem and represents the main information gap in the available literature associated with the topic. Typically, these concepts can be defined as "... very abstract ... and therefore supported by very few practitioners or researchers" [54]. The same idea is endorsed by Wilkinson, who notes that "intellectual capital research is still in the exploration phase, without consensus on the meaning of this concept, and there is little evidence to suggest that such capital could be measured" [55].

The scientific literature on intangible resources [38-41,56-58] and current valuation and reporting regulations suggest the absence of accepted or reliable interpretations of these terms, even though there is consensus on two key features, namely value and information: "Intellectual capital and intangible assets in the context of information are considered determinants of organizational value" [59].

With reference to the formal sizing of intangible resources, we note that there is no universally established classification system, which is why different taxonomies are described in distinct forms in the scientific literature. We consider that the processes of value creation and value maximization in an organization could be improved through the use of intangibles indices. The integrated indicator of intangible resources should be able to meet benchmarking requirements for all types of organizations and sizes.

In this study, we start from the following premise: the implementation of sustainability at the corporate level leads to the development of intangible resources, resulting in an increase in the value of an organization. The main question that we have considered in our research is how we can evaluate intangible resources to help maximize the value of an organization. Our research goal is to find a method on how to assess intangible resources by proposing a new model of assessing and monitoring intangible resources. The intangible resource index can be used globally for comparisons based on publicly available data.

To achieve this goal, the methodology is based on principal components analysis, which identifies and analyses the factors that influence most intangible resources. From the multitude of these variables, we select and choose those that incorporate the greatest amount of common variability, which will generate orthogonal factors using the SPSS software.

The research results support the practical implementation of intangible resource management. The main contributions to this article are presented as follows: It is one of the few scientific articles to focus on the binomial of corporate sustainability-the development of intangible resources. It is difficult to identify whether any research has considered intangible resources to be relevant for sustainability or has more explicitly undertaken to evaluate the effect of implementing corporate sustainability principles on the growth of a company's intangible resources, so this is an under-researched subject. Most of the literature has focused mainly on one of the concepts presented above or on its causality with other parameters; for example, analysis results on the connection between firm-level sustainable practices and corporate reputation [60-62], research on corporate sustainability and business strategy organizational capabilities $[63,64]$ as well as the connection between corporate sustainability and business efficiency $[65,66]$, the effect of corporate sustainability on financial results $[67,68]$, or the connection between sustainability performance and a company's performance [69]. Further research explores the synthesis of corporate sustainability and strategic management [70]. On the other hand, 
there are studies that investigate the impact of investment in core intangible capital and skills of businesses for a sustainable competitive advantage, performance or acquisition of resources [71,72], and intangible assets as regards the correct value of the business [52]. Contributions have also been made with a focus on the research on the performance of intangibles in open innovation processes [53,73] or dedicated to individual intangibles and their valuation in financial terms [74].

Another essential contribution of the article is that we have managed to offer a simplified model of intangible resource assessment, one based exclusively on freely accessible information for each of the proposed components. Therefore, the aim of this study has been to contribute to the practical implementation of the management of intangible resources by offering an autonomous and objective instrument, which uses just openly available information, thus facilitating comparisons between companies. In addition, evaluating intangible assets through open information enables scientists to improve the consistency of the model and develop the sample size (although it is difficult, virtually impossible, to capture the entire business reality using any type of evaluation model, including this one).

The remainder of this article is structured as follows: Section 2 presents conceptual approaches and assessments on the impact of sustainability on intangible resources. A review of the literature explains critical concepts, such as corporate sustainability and intangible resources. This section also discusses the main challenges within companies: intangible resources are not generally comprehended or well managed, even though they have a significant impact on corporate value. It then explains to what extent sustainability and intangible resources relate to the topic at hand. In the third part, a new proposal of intangible recognition and evaluation is made by way of a factorial model. The research methodology is also presented here, and empirical results are mentioned and discussed. The findings of the study are outlined in the last part of the article.

\section{Conceptual Approaches to and Assessments of the Impact of Sustainability on Intangible Resources}

\subsection{Explaining the Corporate Sustainability Concept}

The WCED (World Commission on Environment and Development) released a report in 1987 called Our Common Future, which transformed sustainability into a global concept. In this report, sustainability was linked to the social equity, environmental integrity, and economic prosperity of corporations, using the concept of sustainable development. This is defined as "development that meets the needs of the present without compromising the ability of future generations to meet their own needs" [75] (p. 43). Corporate sustainability is another concept that studies sustainability at the organizational level. Scientific literature provides distinctive definitions for this concept [11].

These definitions vary depending on the given understanding of the concept of corporate sustainability: some definitions consider it a subject in the field of ecology [76], others consider it to be a social duty of an organization [77], while still others develop the concept by integrating economic activities and processes at corporate level and concerns to protect the natural and social environment [78-82].

In any case, corporate sustainability can be seen as a new paradigm in the field of corporate governance, which is an alternative to the classic profit creation and maximization model of a company's main objective. This evolving paradigm considers that, while profit creation and maximization are crucial, there are other objectives that must be pursued by companies, with an impact on society, such as those related to sustainable development.

The new corporate sustainable construction is built on three pillars [83]: one is economic integrity, another is social equity and value, and the third is environmental integrity. It is clear that the combination of these factors will help companies to become sustainable by achieving long-term development goals, thus increasing efficiency and shareholder value.

Corporate sustainability seeks to create long-term value for organizations through the implementation of an integrated corporate plan addressing social, environmental, and economic 
issues. Sustainable management promotes the long-term sustainability of a company as it is more proactive than reactive. The objective is to turn organizations in a direction that contributes, within the ecosystem's limits, to the sustainable development of the economy and society. Leaders, executives, and businessmen are challenged to make a personal, organizational, and societal contribution to sustainable development. The approaches developed are designed to promote sustainability, transparency, and the proper development of staff within organizations. This may take a number of forms, including investing in fair trade goods, reducing packaging materials, and maintaining safe working conditions in factories.

\subsection{Explaining the Concept of Intangible Resources and their Components}

Intellectual capital, based on the different definitions set out in the scientific literature, can be identified as an entity's economic worth, provided by three categories of interdependent intangible elements: human capital [84-90], structural capital [51,85,87-91], and relational capital [51,84,87-92]. All of these three elements, seen as a unitary whole, generate economic benefits for the entity.

In line with the above-mentioned models and taking into account the current difficulties encountered in the conceptualization and structuring of intangible resources, a two-level IR framework dividing each of the two IR components into two elements is introduced in this research (following a previous study of ours [93]). This taxonomy is presented in Table 1. For the purposes of this analysis, we used a set of items and metrics for these IR components, the choice of which is explained in the methodology part of this paper.

Table 1. A proposal for intangible resources components.

\begin{tabular}{|c|c|c|c|}
\hline \multicolumn{4}{|c|}{ Intangible Resources } \\
\hline \multicolumn{2}{|c|}{ Knowledge Resources on Individual Level } & \multicolumn{2}{|c|}{ Organizational Intangible Resources } \\
\hline $\begin{array}{l}\text { Informal Knowledge: Native; } \\
\text { Acquired; HUMAN CAPITAL }\end{array}$ & $\begin{array}{l}\text { Formal Knowledge: } \\
\text { INNOVATIVE CAPITAL }\end{array}$ & $\begin{array}{l}\text { Organization-level Resources: } \\
\text { STRUCTURAL CAPITAL }\end{array}$ & $\begin{array}{l}\text { Group-level Resources: } \\
\text { Alliance Resources; } \\
\text { Reputation Resources; } \\
\text { RELATIONAL CAPITAL }\end{array}$ \\
\hline
\end{tabular}

Source: from the authors' point of view.

Knowledge resources are the first components of intangible resources. In the structure proposed by us, we started with the form of knowledge that is the basis of these kind of resources. The two concepts of knowledge are separated by the type of knowledge at issue, i.e., informal or formal.

Informal information concerns concepts, facts, theories, interpretations, questions, decisions, myths, stories, and perspectives. All of these components are part of human capital (HC) as it comprises the knowledge, skills, and expertise of the employees in a company [94,95]. Informal knowledge can be generated by the following:

- Native values (genetic heritage, imagination, talents, intellectual capacity, beliefs, and moral values);

- Values acquired over time (awareness, experience, schooling, talents, competencies, and abilities).

On the other hand, formal knowledge is codified-registered in manuals and other types of documentation-and reflects "organizational intelligence" or innovation capital (IC). Formal knowledge is an asset generated by the transfer of information from one brain entity to another, articulated in a permanent form-one that is easier to recognize and to communicate. Another advantage of formal knowledge is that it is possible to measure and protect intellectual property in this process. The tools of intellectual property are those which fall within the scope of legal or contractual rights, including trademarks, copyrights, patents, etc.

Organizational intangible resources represent the second important group of intangibles. Considering Brătianu's view, [96] which states that the structure is part of the organization, not vice versa, we may assume structural capital (SC) (resources at the organizational level) constitutes the first component of organizational intangibles. It refers to human capital infrastructure, including 
organizational skills that help an organization respond to business demands (including the philosophy and theory of management, information technology, organizational culture, administrative processes and procedures, research initiatives, and IT technology and network systems acquisition). It is formed by structured knowledge held by the organization and is shared (databases, procedures, etc.).

The other component, i.e., relational capital (RC) (resources at a group level), is defined by all the relations between the organization and its stakeholders. RC describes external relations between the organization and a wide range of economic agents: consumers, vendors, government, mass media, and other stakeholders [94,95]. The more a company learns and cares about its clients, the more competitive it is $[94,97,98]$. In our opinion, $\mathrm{RC}$ is divided into resource alliances, focusing on external ties with the company that operates and manages the business (relationships with stakeholders, such as the suppliers, investors, funders, collaborations, and contracts, including university networks and collaborations) and reputational resources (prestige, social responsibility, entity image, brand, and advertising). The value of the relationships that an organization maintains with the stakeholders (especially with the clients) is reflected in the concept of goodwill.

\subsection{The Big Challenge: Intangible Resources Are Not Commonly Recognised or Managed Given Their Effect on Value Creation}

The obsolete dependence on traditional physical resources and financial resources is no longer able to provide clear competitive advantages. As a result, companies seek to differentiate themselves through other types of resources used in their activities, with an emphasis on the intangible ones. Our view, held by most analysts [99], is that intangible resources account for about $80 \%$ of the value of most companies today. This contrasts sharply with the situation as recent as 30 years ago, when the figure was $30 \%$.

The challenge faced by an organization is to find ways to develop its intangible resources systematically. It is complicated, as intangible resources are hard to pin down intrinsically. Focusing on issues that are observable, i.e., revenue, profitability, profits, physical assets, and others, is much simpler. To help to refocus efforts on intangible resources, firms should put strategies in place to build their strengths in each region. One way to do this is to leverage company strategies that can be easily realigned and implemented in intangible resources growth.

Measuring intangible resources and intellectual capital has become a major research field for researchers and practitioners, who have intensified concerns about tracking and analyzing this kind of capital. There are a number of methods used to measure intangible resources, the Skandia Navigator [50], the Intangible Asset Monitor [100], IC Rating [101], and InCaS-Intellectual Capital Statement [95]. A large number of different methods (over 30) are identified in the works of Canibano, Garcia-Ayuso, and Sanchez [38], Bontis [84], Bontis [85], Sveiby [100], Petty and Guthrie [102], Williams [103], Andriessen [104], Tan, Plowman and Hancock [105], Jurczak [106], and others.

Given these circumstances, it is not possible to harmonize relevant approaches to these problems, resulting in managements currently facing real difficulties in assessing and calculating the aforementioned resources. The recognition of intangibles and of intellectual capital is a highly discussed subject and one that is investigated with a degree of restraint, as there are no clearly defined principles and rules regarding it, either at national or international level.

Although intangible resources are key factors when it comes to the value held by organizations in the knowledge economy, accounting standards do not recognize this change-from tangible to intangible resources-in evaluating organizations.

As a result, there is a serious disparity between what is happening in the capital markets and what accounting systems reflect. The book value is based on historical costs (of the assets, etc.), while the market value is formed from the expectations of the future cash flows of an organization, which is largely due to the intangible assets, such as the know-how of employers, research, and development activities and so on. Thus, leaving us somewhat uncertain, investors must rely heavily on assumptions to judge the accuracy of an organization's value. 
In the methodology part of this study, we suggest a simplified model of evaluation of intangible resources, based solely on publicly accessible data for each of the elements suggested in its framework, in line with Molodchik, Shakina, and Barajas [94], who explored the plausibility of six elements of intellectual capital, in order to provide managers with instruments to promote the decision-making process in the field of intangible resources.

\subsection{The Link between Sustainability and Intangible Resources}

The three corporate sustainability foundations linked to economic, social, and environmental issues work together to help companies to aim for more sustainable practices. Businesses need to switch from an outdated sense of quick profits at the cost of the environment to a more cooperative interdependence and eco-innovation. Adopting sustainable practices improves the environment and the business itself-companies have proven that sustainability programs contribute to an enhanced brand image, decreased costs, happy shareholders, increased profitability, and many other benefits [107]. Companies may explore the connection between sustainability and the intangible resources in several ways.

\subsubsection{Knowledge Resources: Human Capital}

The knowledge accumulated in time, expertise, and experience of those working in a corporation is actually "rented" rather than purchased, and therefore can easily be lost to rivals or other businesses. Many employees choose to work for a company that has organizational principles matched with their individual values.

Human capital was established as one of the key factors of sustainability in organizations [78]. In order to address new and complex sustainability challenges, businesses need to balance their short-term, profit-driven priorities with long-term sustainable outcomes. The Internet revolution could provide the green solutions needed for this. E-business is an innovation that promotes sustainable development that is necessary for green growth. From the point of view of human capital, the implementation of e-business brings on an increase in the value of this capital, in conjunction with the commitment and direction of the company as a whole [108].

Sustainability offers a tremendous opportunity by aligning organizational and individual principles around optimistic topics such as good health, recycling, welfare, and doing better. The further corporate-level companies embed sustainability, the more likely it is that workers find greater sense and purpose in their jobs. It, in effect, encourages employee satisfaction, retention, and productivity [13]. Job satisfaction is linked to organizational commitment, which relates positively to organizational sustainability $[78,79]$.

\subsubsection{Knowledge Resources: Innovation Capital}

The social cornerstone of corporate sustainability is represented by the involvement of workers, stakeholders, and the community. The fair treatment of workers and a supportive supply chain process leads to improved efficiency and innovation and helps to develop high retention and commitment. Businesses with a strong emphasis on R\&D create better quality products and services $[109,110]$. Overall, the long-term implementation of sustainable social policies results in a workforce that has more expertise and inspiration. Creating a healthy, community-oriented culture promotes a creative workforce. They grow into a workforce who can strengthen current goods, processes, and business models. The social foundation, on a global scale, means understanding where and how to fill the supply chain. This is achieved by sustainable labor, a healthy work climate, equal wages, and community support.

\subsubsection{Organizational Intangible Resources: Relationship Capital}

When amplified by constructive interactions, the value attached to relationships becomes active. Connectivity and collaboration — not only with consumers, vendors, and other stakeholders, but also internally—is essential for the establishment of successful and sustainable ties. 
Sustainability offers a shared platform where people can work together without being too worried about economic pressures and internal politics. Positive relationships can be enhanced by mutually cooperative supplier systems, customer engagement networks, and employee initiatives focused on sustainability.

The value of the economic cornerstone of corporate sustainability lies in the balance between benefits and ethics. However, though a shift in the supply chain can bring short-term financial gains, it should be treated with extreme suspicion if the credibility of the company is at any risk of possible harm. The economic foundation, on the other hand, also provides a counterweight to drastic environmental initiatives that companies are often forced to implement, such as eliminating fossil fuels entirely.

The relational component of intangible resources involves promoting relationship commitment, integrating resources and partners' skills, avoiding opportunistic behavior, and also building the company relationships on a shared trust and commitment to long-term cooperation. It reduces the insecurity of partners and helps them invest in the tangible and intangible resources that are required and also in new technologies and operations that carry revenues later [108].

Ultimately, corporate policies should not be self-defeating or damaging to their image and long-term growth. The economic foundation basically helps companies to continue to make adjustments to sustainability at a steady and financially stable pace.

A brand is built through the consistent dramatization of a simple and succinct value proposition. A well-known brand also improves customer loyalty and creates a corporate identity [109,111,112].

Although brand values traditionally fell within the competence of the marketing department, all individuals within an organization now have the responsibility to convey such values through their actions. Sustainability is essential to the creation of brand capital, because sustainability messages appear to be coordinated and implemented consistently. Rallying workers around an initiative for sustainability will help to create persistent, idiosyncratic habits that drive brand value.

\subsubsection{Organizational Intangible Resources: Structural Capital}

Of all three, the corporate sustainability environmental element is the most critical. Sustainable companies are also the most creative as they continually evaluate organizational resources to meet customer demands, adjust internal processes from within to find better, greener alternatives. Corporations are also likely to see a positive effect on their public image and financial returns by reducing their packaging waste and carbon footprint. Some specific strategies that help businesses to save money and reduce their effect on the environment include introducing transport management systems, reducing carbon emissions, and improving packaging. As awareness about environmental concerns increases, it is important to have a green sustainability campaign to create an environmentally friendly reputation with consumers.

Despite the benefits of value creation and maximization, connecting sustainability with intangible resources is critical to aligning social and environmental programs with an organization's core competencies. Structural capital represents a shared perception of the internal information structures, processes, and regulations of the organization. The paper emphasizes the knowledge management system, an aspect widely supported by other empirical studies $[98,113]$.

\section{New Proposal on Intangible Recognition and Evaluation: The Factorial Model}

The study used two-level IR decomposition (similar to studies $[94,95,101])$ and aimed to find specific metrics for each component of the IR. For each IR component, the research identified specific items and indicators. Identifying the items was done in two phases. Firstly, a list of potential variables was drawn up from theoretical and empirical studies (see Table 2). The main criterion for determining the metrics in the model was the public availability of data. 
Table 2. Indicators proposed for analysis.

\begin{tabular}{ccc}
\hline Number & Indicators & $\begin{array}{c}\text { Category of Intangible Resources } \\
\text { Where They Are Included * }\end{array}$ \\
\hline 1 & Number of employees (quantitative indicator of human resources) & HC \\
2 & Annual productivity (sales divided by the number of employees) & HC \\
3 & Experience and training of management team & HC \\
4 & Wage costs per employee (indicator of their motivation) & HC \\
5 & Net profit per employee & HC \\
6 & Presence of a knowledge management system & SC \\
7 & Investments in research and development (related to total & IC \\
8 & expenditures) & IC \\
9 & Value of intangible fixed assets & IC \\
10 & Awards for innovation performance & RC \\
11 & Degree of online penetration (online search engine queries) & RC \\
12 & Number of subsidiaries & RC \\
\hline
\end{tabular}

Source: from the authors' point of view. * Human capital (HC), structural capital (SC), innovation capital (IC), relational capital (RC)

Secondly, because there is a large number of factors or variables with different influences on intangible resources, principal component analysis was used, a method of factor analysis that identified and analyzed those variables that significantly influence intangible resources. The empirical part of this paper is a database of 13 of the most liquid companies trading on the secondary regulated capital market in Romania, the components of the Bucharest Exchange Trading (BET) Index. We used the SPSS software to carry out an analysis of the main components that influence intangible resources, through which we aimed at achieving a representative key index, which could be the decision element to prioritize specific measures and actions to ensure an optimum level of intangible resources and their superior quality. From the multitude of available indicators that influence intangible resources, we selected and chose those that incorporated the greatest amount of common variability that generated orthogonal factors.

\subsection{Substantiating Items and Metrics for Intangible Resource Elements in the Model}

The intangible resource taxonomy proposed by us in one of our previous research studies [93] was used in order to structure the entirety of intangible resources that we considered in the study, according to which four components of intangible resources can be identified: human, innovation, structural, and relational capital. Based on the scientific literature, each item was identified by indicators that were only collected on the basis of data accessible to the public (and they can be found in Table 2). The methods for measuring these indicators are described below, in the data collection part.

\subsubsection{Human Capital}

The first component of intangible resources, human capital, is an integral part of intangibles, because it represents the resources created by the workforce. In this context, we considered it necessary to look into the effectiveness of staff by measuring the results. We therefore used two indicators from this perspective: productivity, one of the indicators most commonly used in analyses $[114,115]$ and net profit per employee, perceived as an important indicator of the return on human capital (Mondy and Noe [116] claim that employee return is a primary HR attribute). We considered that expertise and managerial skills play an essential part in the success of implementing a system of intangible resources. This is why we deemed it appropriate to analyze the level of training and experience of top management (according to $[98,117])$. We developed a scale for this analysis to measure the competence of top managers based on the details given in their annual reports by organizations. Motivation costs can reflect a company's ability to cover workforce expenditures and management compensation [115], based on the value that human resources produce in the organization. Related to human capital, another indicator of interest is the size of this capital, assessed by the number of 
employees. This indicator is typically used to approximate the size of an organization, which outlines the scale and shape of the HC of a company [100].

\subsubsection{Innovation Capital}

Concerning innovation capital, we considered it important for organizations to be able to conceive and absorb innovations. The ability to measure investment in R\&D (related to overall expenditure) is a key factor in this. Intensively focusing on this area, organizations that promote significant investment in research and development produce new, innovative, and effective products and services on the market $[109,110]$; recognition of their ability to innovate (through numerous awards for innovation performance) is therefore one of the most effective ways to gain new market shares (in line with Molodchik, Shakina, and Barajas, [94]). Organizations that win awards for their products in the industry are becoming more and more relevant. At the same time, innovation capital is often reflected in the valuation of intangible assets held by the respective organizations, so this study analyzed intangible assets using their book value [94].

\subsubsection{Structural Capital}

Structural resources describe organizationally integrated knowledge frameworks, policies, and regulations. We, therefore, highlighted one important aspect of structural capital here: the establishment of a knowledge management system. This dimension represents a common understanding of organizationally embedded information systems and knowledge procedures and regulations and is supported in different studies $[98,113]$.

\subsubsection{Relational Capital}

The last dimension of intangible resources is relational capital, one of the most important conditions for business performance. However, given that we attempted to analyze the intangible resources of companies through the use of publicly available data in this report, it is difficult to identify a company's entire relational network. On the one hand, we considered the degree of online penetration (online search engine queries) to represent a company's popularity (in line with Arnott and Bridgewater [118]). It is vital for a company to be active in as many professional organizations as possible and to establish its representations in close proximity to the services that the company uses or to the market that it wishes to join $[119,120]$. These elements were calculated by the number of subsidiaries per organization in this study (in line with Molodchik, Shakina, and Barajas, [94]). Additionally, advertising expenses related to the financial statements of the companies were considered to be investments in support of the companies [121].

To sum up, for the purpose of this research, an organization's intellectual resources represent a dynamic system influenced at each moment by several factors, such as the number of employees, annual productivity (sales divided by the number of staff), experience and training of the management team, wage costs per employee (an indicator of their motivation), net profit per employee, presence of a knowledge management system, investments in research and development (related to total expenditures), value of intangible fixed assets, awards for innovation performance, degree of online penetration (online search engine queries), number of subsidiaries, advertising costs, etc.

\subsection{Research Methodology}

\subsubsection{Study Sampling}

In order to improve the generalization of the results obtained, this study covered a wide range of economic sectors, including financial intermediation and insurance; extractive industries; production and supply of electricity, heat, gas, hot water, and air conditioning; professional, scientific, and technical actions; information and communications; transport and storage; and health and social assistance. The companies analyzed are the 13 companies included in the calculation of the BET Index (Bucharest 
Exchange Trading) (the make-up of this index in September 2019 is shown in Table 3), which is the first index developed by the Bucharest Stock Exchange (BVB) and represents the reference index of the Romanian capital market. Liquidity is the main selection criterion for companies in the index.

Table 3. Bucharest Exchange Trading (BET) Index composition (September, 2019).

\begin{tabular}{cc}
\hline Company Symbol & Activity Sector \\
\hline FP & Financial intermediation and insurance \\
TLV & Financial intermediation and insurance \\
SNP & Extractive industry \\
SNG & Extractive industry \\
BRD & Financial intermediation and insurance \\
TGN & Production and supply of electricity, heat, gas, hot water, and air \\
EL & conditioning \\
DIGI & Professional, scientific, and technical actions \\
TEL & Information and communications \\
COTE & Production and supply of electricity, heat, gas, hot water, and air \\
SNN & conditioning \\
M & Transport and storage \\
BVB & Production and supply of electricity, heat, gas, hot water, and air \\
& conditioning \\
& Financial intermediation and insurance \\
\hline
\end{tabular}

For the analysis, the values for the 12 intangible resource indicators for the 13 companies included in the BET Index were extracted in order to have an overall view of the representative companies on the Romanian capital market. The financial statements of these companies were collected from the financial information provided on the Bucharest Stock Exchange website. Because the sample size was not large, this could have had an impact on the robustness of the model. In this research, however, we intended to present a conceptual model for the assessment of intangible resources that could be developed in future research using a much larger sample of companies. The data were for the year 2018 and represent the annual information on the indicators proposed in the model.

\subsubsection{Data Collection}

Each component of the intangible resources discussed above was described in a set of indicators collected only on the basis of publicly available data. As a result, the data sources used were mainly the annual reports of the companies available on the Bucharest Stock Exchange site: data were also collected by accessing the companies' websites. More specifically, the data sources and methods for measuring these indicators are described in Table 4. In the case of an analysis of the level of education and experience of top management, we developed a scale for estimating top managers' skills based on the annual reports of the organizations. In the case of innovation performance, if details of the innovation performance awards appeared on a company's website, we gave a score of 1 , otherwise 0 . We used online search engine queries to analyze the degree of online penetration. The score obtained by each company (0-min ... 10-max) was identified on the website [123]. It should be noted that there may be some limitations to the methods of data collection based on company-specific websites, for indicators such as the presence of a knowledge management system, awards for innovation performance, or the number of subsidiaries. 
Table 4. Source of information and method of measurement for intangible resources (IR) indicators in the study.

\begin{tabular}{|c|c|c|}
\hline Number & Proposed Indicators & Source of Information and Method of Measurement \\
\hline $\mathrm{V}_{1}$ & $\begin{array}{c}\text { Number of employees (quantitative indicator } \\
\text { of human resources) }\end{array}$ & Company Annual Report (CAR). \\
\hline $\mathrm{V}_{2}$ & Annual productivity (Sales divided by the & "Financial data" and "Common information" from CAR. \\
\hline $\mathrm{V}_{3}$ & $\begin{array}{l}\text { Experience and training of the management } \\
\text { team }\end{array}$ & $\begin{array}{l}\text { "Common information" from CAR.If more than one third } \\
\text { of managers have a postgraduate qualification standard } \\
\text { and more than five years of experience: } 2 \text { points. If more } \\
\text { than one third of managers have a postgraduate degree or } \\
\text { more than five years of experience: } 1 \text { point. Otherwise: } 0 \text {. }\end{array}$ \\
\hline $\mathrm{V}_{4}$ & $\begin{array}{c}\text { Wage costs per employee (indicator of their } \\
\text { motivation) }\end{array}$ & \\
\hline $\mathrm{V}_{5}$ & Net profit per employee & "Financial data" from CAR. \\
\hline $\mathrm{V}_{6}$ & Presence of a knowledge management system & $\begin{array}{l}\text { Website of the company. If it includes details about its } \\
\text { existence: } 1 \text {, otherwise: } 0 .\end{array}$ \\
\hline $\mathrm{V}_{7}$ & $\begin{array}{l}\text { Investments in research and development } \\
\text { (related to total expenditures) }\end{array}$ & "Financial data" from CAR. \\
\hline $\mathrm{V}_{8}$ & Value of intangible fixed assets & "Financial data" from CAR. \\
\hline $\mathrm{V}_{9}$ & Awards for innovation performance & $\begin{array}{l}\text { Website of the company. If it includes details about their } \\
\text { existence: } 1 \text {, otherwise: } 0 \text {. }\end{array}$ \\
\hline $\mathrm{V}_{10}$ & $\begin{array}{c}\text { Degree of online penetration (online search } \\
\text { engine queries) }\end{array}$ & $\begin{array}{l}\text { Identified the score obtained by each company }(0-\min . . . \\
\text { 10-max) on the site: } \\
\text { www.prchecker.info/check_page_rank.php }\end{array}$ \\
\hline $\mathrm{V}_{11}$ & Number of subsidiaries & Website of the company. \\
\hline $\mathrm{V}_{12}$ & Advertising costs & "Financial data" from CAR. \\
\hline
\end{tabular}

\subsubsection{Data Analysis}

There is a large number of factors or variables with different influences on intangible resources, so finding certain factors with a major determinant function in optimizing their level is useful. A solution to this issue could be to apply a factor analysis approach, such as principal component analysis, which identifies and analyses those variables that significantly influence intangible resources.

Principal component analysis, also called the Hotelling Transformation or Karhunen-Loeve Transformation, actually uses a mathematical concept, namely "eigenvector" (the solution of a matrix equation of the form $(A-\lambda I) x=0, x \neq 0)$, and seeks to limit the number of variables initially used with a small number of representative variables, i.e., reducing a large data volume to a structure that retains as much common variability as possible [124].

In the following, we will use the SPSS software to analyze the principal components that influence intangible resources, by means of which we shall aim to achieve a key, representative indicator that may be constituted in a decision maker to prioritize specific measures and actions to ensure an optimal level and a high quality of intangible resources.

Of the many available indicators influencing intangible resources, we shall select and choose those which incorporate the greatest amount of common variability that will generate orthogonal factors. We shall start from the following twelve indicators, as factors/variables of intangible resources level: the number of employees; annual productivity (sales divided by the number of employees), experience and training of the management team, wage costs per employee (an indicator of their motivation), net profit per employee; presence of a knowledge management system, research and development spending (relating to overall expenditure), value of intangible fixed assets, awards for innovation performance, degree of online penetration (online search engine queries), number of subsidiaries, and advertising costs.

\section{Research Results}

The solution of the problem raised consists in identifying the orthogonal factors out of the available ones and subjected to the factorial analysis, using SPSS software version 17, following several steps outlined below. 
Step 1

To solve the problem we used the variables and data that we entered in the Variable View and Data View windows of the SPSS software version 17 (in Figure 1 we presented the Data View window, where all the data were gathered for the 12 variables: V1-V12 are the indicators in Table 4).

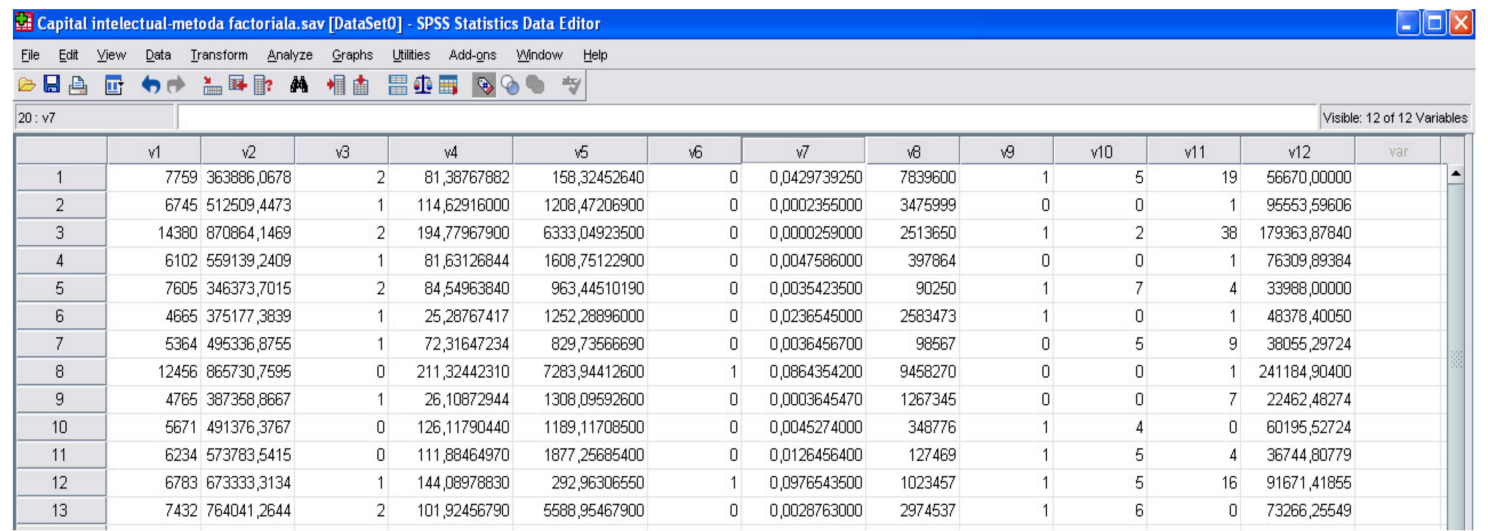

Figure 1. Data View window. Source: following the authors' own analysis. Generated by SPSS.

Step 2

We used the dialogue Analyze-Dimension Reduction-Factor.

Step 3

We entered the variables to be processed in the Variables list. Subsequently, in the Selection Variable field, we indicated the variable by selecting the observations analyzed according to Value.

We set the analysis parameters in the dialogues displayed according to the following options: Descriptives, Extraction, Rotation, Scores, Options.

Step 4

By accessing the Descriptives option in the Statistics group, we requested the display of elementary statistics elements (such as media, standard deviation, etc.). Then we selected the Initial solution, and the software displayed the initial communalities, eigenvalues, etc.

Step 5

By accessing the Extraction option in the Method list, we selected the factorial analysis method, and, in order to perform the principal component analysis, we selected the Principal components. Thus, the type of analysis is represented by the Correlation matrix.

In the Extraction option group, we listed the twelve factors selected and specified in the problem statement, as well as the threshold of a unit for eigenvalues.

By selecting the Scree Plot option, we generated a chart of eigenvalues, by means of which a number of factors could be determined, and, by selecting the Unrotated Factor Solution option, the software displayed the commonalities and eigenvalues of the variables in the correlation matrix.

Because the problem is solved by means of an iterative process, we set number 25 as the maximum number of iterations in Maximum Iterations for the Convergence option.

Step 6

By accessing the Rotation option in the window displayed, we set the varimax method, and the maximum number of iterations to 25, in Maximum Iterations for Convergence, to minimize the number of variables and to simplify the interpretation of the factors under analysis. 
Step 7

We accessed the Scores option and Regression calculation method to obtain new variables of the final factorial scores.

\section{Step 8}

When the Display factor score coefficient matrix option was ticked, the software displayed, subsequent to the component matrix (Table 5) and the component matrix following Rotation (Table 6), the correlation matrix that is shown between the scores and the coefficients by which the variables must be multiplied in order to obtain the factorial scores (Table 7).

Table 5. Component matrix displayed by the SPSS software.

\begin{tabular}{ccccc}
\hline Component Matrix & a \\
\hline & & Component & \\
\hline & $\mathbf{1}$ & $\mathbf{2}$ & $\mathbf{3}$ & $\mathbf{4}$ \\
\hline Investments in research and development $\left(\mathrm{V}_{7}\right)$ & 0.971 & -0.094 & -0.151 & 0.026 \\
Wage costs per employee $\left(\mathrm{V}_{4}\right)$ & 0.899 & 0.114 & 0.081 & -0.283 \\
Experience and training of management team $\left(\mathrm{V}_{3}\right)$ & -0.101 & 0.758 & -0.166 & 0.463 \\
Degree of online penetration $\left(\mathrm{V}_{10}\right)$ & -0.218 & 0.612 & 0.552 & -0.268 \\
Advertising costs $\left(\mathrm{V}_{12}\right)$ & 0.572 & -0.280 & 0.710 & 0.267 \\
Number of employees $\left(\mathrm{V}_{1}\right)$ & 0.882 & 0.360 & -0.206 & 0.043 \\
Number of subsidiaries $\left(\mathrm{V}_{11}\right)$ & 0.365 & 0.675 & -0.046 & 0.274 \\
Awards for innovation performance $\left(\mathrm{V}_{9}\right)$ & -0.060 & 0.689 & 0.478 & -0.158 \\
Annual productivity $\left(\mathrm{V}_{2}\right)$ & 0.679 & -0.360 & 0.570 & 0.054 \\
Presence of a knowledge management $\left(\mathrm{V}_{6}\right)$ & 0.870 & 0.102 & -0.110 & -0.349 \\
Value of intangible fixed assets $\left(\mathrm{V}_{8}\right)$ & 0.803 & 0.112 & -0.377 & -0.218 \\
Extraction method: principal component analysis. & 0.630 & -0.156 & 0.014 & 0.572 \\
\hline
\end{tabular}

Source: following the author's own analysis. Table generated by SPSS. a. 4 components extracted.

Table 6. Component matrix after Rotation, displayed by the SPSS software.

\begin{tabular}{|c|c|c|c|c|}
\hline \multicolumn{5}{|c|}{ Rotated Component Matrix ${ }^{a}$} \\
\hline & \multicolumn{4}{|c|}{ Component } \\
\hline & 1 & 2 & 3 & 4 \\
\hline Investments in research and development $\left(\mathrm{V}_{7}\right)$ & 0.844 & 0.406 & -0.300 & 0.097 \\
\hline Wage costs per employee $\left(\mathrm{V}_{4}\right)$ & 0.881 & 0.341 & 0.122 & -0.026 \\
\hline Experience and training of management team $\left(\mathrm{V}_{3}\right)$ & -0.087 & -0.213 & 0.188 & 0.859 \\
\hline Degree of online penetration $\left(\mathrm{V}_{10}\right)$ & -0.116 & -0.020 & 0.880 & 0.105 \\
\hline Advertising costs $\left(\mathrm{V}_{12}\right)$ & 0.137 & 0.975 & 0.076 & -0.069 \\
\hline Number of employees $\left(\mathrm{V}_{1}\right)$ & 0.859 & 0.188 & -0.042 & 0.420 \\
\hline Number of subsidiaries $\left(\mathrm{V}_{11}\right)$ & 0.339 & 0.046 & 0.229 & 0.704 \\
\hline Awards for innovation performance $\left(\mathrm{V}_{9}\right)$ & 0.008 & 0.026 & 0.812 & 0.267 \\
\hline Presence of a knowledge management system $\left(\mathrm{V}_{6}\right)$ & 337 & 0.867 & 0.015 & -0.233 \\
\hline Annual productivity $\left(\mathrm{V}_{2}\right)$ & 933 & 0.170 & 0.026 & -0.048 \\
\hline Net profit per employee $\left(\mathrm{V}_{5}\right)$ & 0.897 & 0.000 & -0.183 & 0.091 \\
\hline Value of intangible fixed assets $\left(\mathrm{V}_{8}\right)$ & 0.276 & 0.601 & -0.423 & 0.364 \\
\hline
\end{tabular}

Source: following the author's own analysis. Table generated by SPSS. a. 4 components extracted. 
Table 7. Correlation matrix, displayed by the SPSS Software.

\begin{tabular}{ccccc}
\hline \multicolumn{5}{c}{ Component Score Coefficient Matrix } \\
\hline & $\mathbf{1}$ & Component & \\
\hline & $\mathbf{1}$ & $\mathbf{3}$ & $\mathbf{4}$ \\
\hline Investments in research and development $\left(\mathrm{V}_{7}\right)$ & 0.164 & 0.047 & -0.121 & 0.028 \\
Wage costs per employee $\left(\mathrm{V}_{4}\right)$ & 0.250 & -0.011 & 0.158 & -0.144 \\
Experience and training of management team $\left(\mathrm{V}_{3}\right)$ & -0.106 & -0.002 & -0.045 & 0.553 \\
Degree of online penetration $\left(\mathrm{V}_{10}\right)$ & 0.025 & 0.030 & 0.501 & -0.064 \\
Advertising costs $\left(\mathrm{V}_{12}\right)$ & -0.153 & 0.505 & 0.073 & 0.027 \\
Number of employees $\left(\mathrm{V}_{1}\right)$ & 0.189 & -0.041 & -0.021 & 0.180 \\
Number of subsidiaries $\left(\mathrm{V}_{11}\right)$ & 0.015 & 0.029 & 0.045 & 0.398 \\
Awards for innovation performance $\left(\mathrm{V}_{9}\right)$ & 0.026 & 0.045 & 0.443 & 0.045 \\
Presence of a knowledge management system $\left(\mathrm{V}_{6}\right)$ & -0.037 & 0.381 & 0.082 & -0.122 \\
Annual productivity $\left(\mathrm{V}_{2}\right)$ & 0.301 & -0.120 & 0.108 & -0.170 \\
Net profit per employee $\left(\mathrm{V}_{5}\right)$ & 0.286 & -0.193 & -0.046 & -0.051 \\
Value of intangible fixed assets $\left(\mathrm{V}_{8}\right)$ & -0.134 & 0.312 & -0.291 & 0.348 \\
Extraction method: principal component analysis. & & \\
Rotation method: varimax with Kaiser normalization. & & \\
component scores. & & & \\
\hline
\end{tabular}

Source: following the author's own analysis. Table generated by SPSS.

Step 9

After pressing the Options button, we requested the determination of the method of treating missing values as well as the method of displaying matrices, by ticking the Exclude cases listwise command so as to omit the coefficients whose absolute value was less than the threshold of a unit.

Step 10

The Total Variance Explained Table displayed by the SPSS software provided the first factor-specific information. In this table, we could see the key components, also called variables, i.e., those given unitary or super-unitary eigenvalues.

The Extraction Sums of Squared Loadings columns in the Total Variance Explained table were those found in the Total column values for eigenvalues. They also contained the explained variance (percent of Variance column) and cumulative variance (cumulative percent column) in the initial solution before rotation. And the Squared Loading column Rotation Sums showed the factor values after the rotation procedure was applied.

The first variable, which can be found in the second column in Table 8, explained the corresponding variance of 5.31 components and the second one the variance of 2.286 components. The third component explained the variance of 1.619 variables and the fourth one the variance of 1.039 variables. All the other extracted factors explained less than the variance of a variable.

The first component (variable) in the third column of Table 8 explained $44.254 \%$ of the total common variance of variables and the second one $19.053 \%$. Cumulatively, the first two extracted variables explained $63.307 \%$ of the total common variance of variables.

For the initial solution of the problem solved with the factorial method, according to those entered in column number five of Table 8, the sum of the squares of factorial saturations was 5.310 for the first component, 2.286 for the second component, 1.619 for the third component, and 1.039 for the fourth component.

After the rotation of factors, the sum of the squares of saturations was 4.245 for the first component, 2.258 for the second one, 1.847 for the third one, and 1.705 for the fourth one. We noticed that the proportion of total variance explained cumulated by the four components changed as a result of the rotation of the factors (it was 100\%). The value of saturations for each component (variable) changed, and the sum of the squares of these saturations increased. 
Table 8. Table of Total Variance Explained.

\begin{tabular}{|c|c|c|c|c|c|c|}
\hline \multicolumn{7}{|c|}{ Total Variance Explained } \\
\hline \multirow{2}{*}{ Component } & \multicolumn{3}{|c|}{ Initial Eigenvalues } & \multicolumn{3}{|c|}{ Extraction Sums of Squared Loadings } \\
\hline & Total & $\%$ of Variance & Cumulative $\%$ & Total & $\%$ of Variance & Cumulative $\%$ \\
\hline $1-V_{7}$ & 5.310 & 44.254 & 44.254 & 5.310 & 44.254 & 44.254 \\
\hline $2-V_{4}$ & 2.286 & 19.053 & 63.307 & 2.286 & 19.053 & 63.307 \\
\hline $3-V_{3}$ & 1.619 & 13.491 & 76.798 & 1.619 & 13.491 & 76.798 \\
\hline $4-V_{10}$ & 1.039 & 8.661 & 85.459 & 1.039 & 8.661 & 85.459 \\
\hline $5-V_{12}$ & 0.689 & 5.740 & 91.199 & & & \\
\hline $6-V_{1}$ & 0.464 & 3.865 & 95.063 & & & \\
\hline $7-V_{11}$ & 0.330 & 2.746 & 97.810 & & & \\
\hline $8-V_{9}$ & 0.156 & 1.296 & 99.106 & & & \\
\hline $9-\mathrm{V}_{6}$ & 0.086 & 0.720 & 99.826 & & & \\
\hline $10-V_{2}$ & 0.012 & 0.101 & 99.927 & & & \\
\hline $11-V_{5}$ & 0.008 & 0.071 & 99.998 & & & \\
\hline $12-V_{8}$ & 0.000 & 0.002 & 100.000 & & & \\
\hline Extractio & methoc & rincipal compo & nt analysis. & & & \\
\hline
\end{tabular}

Source: following the author's own analysis. Table generated by SPSS.

The optimal factorial solution is that with the four extracted components (variables) shown in Table 8.

In summary, by using the factorial method and the analysis of the twelve indicators of intangible resources level processed by the SPSS software, we obtained a structure of four orthogonal factors as a final solution, which accumulated the greatest amount of variability common to intangible resources. These factors are part of the category of human capital, structural capital, and relational capital: investments in research and development, wage costs per employee (indicator of their motivation), experience and training of the management team, and the degree of online penetration.

\section{Discussion}

The modeling and simulation results refer to a final solution consisting of a four basic indicator sequence of intangible resources. The variables chosen are investments in research and development, wage costs per employee (indicator of their motivation), experience and training of the management team, and the degree of online penetration. We mark these variables with I1, I2, I3, I4. This sequence is a new indicator of the intangible resource level, a key, a representative indicator, which incorporates the greatest amount of variability common to other available factors in the factorial method (principal component analysis).

We mark the new indicator with IRs. Then, mathematically, it can be written as a vector of R4, as follows:

$$
\text { IRs }=\left(\mathrm{I}_{1}, \mathrm{I}_{2}, \mathrm{I}_{3}, \mathrm{I}_{4}\right)
$$

Intangible resources, first explained by twelve variables in this study, are well defined by only four variables that make a significant contribution to these resources. Investments in research and development appear to be the most significant factor. Another important factor is human capital expenditure, approximated by wage costs per employee, as a measure of their motivation. Management team experience and training make a significant contribution to the IR value. The last significant factor affecting the valuation of intangible assets of the sampled companies is the degree of online penetration. This finding appears to be fair, as it represents a significant impact of the Internet on commerce [88].

In conclusion, by using principal component analysis, we calculated, based on the study of the linear matrix of the variables, the current, subsequent, and successive common variance. The factor containing the greatest amount of variability was extracted, followed by the second factor covering the greatest amount of variability of the remaining variable, etc.

The common character/commonality of the four orthogonal factors reflects the part of their variance which is common to other analyzed measurements. 
Principal components analysis offers practical information to researchers, and provides statisticians and all managers with the opportunity to track the upward or downward evolution of intangible resources.

\section{Conclusions}

The study provides insight into the calculation of intangibles. In view of the fact that the models for evaluating intangible resources found in the scientific literature are mainly based on data specific to each company that applies them, and that making comparisons between companies has virtually no value, this study has put forward a mathematical model that contributes to the practical implementation of intangible resource management by providing an objective and independent approach.

It also overcomes the complexities of scientific research, i.e., the study of substantial data. This study therefore gives further awareness of the IR structure and contributes to the theory of IR management and realistic implementation by improving the decision-making process in this area.

The results of the current study show that investment in research and development is the most important factor in the assessment of IR. Most previous studies [125-127] show that intangible capital factors, such as investment in $R \& D$, have statistically significant effects on the market-based value generated by intangible resources. These findings suggest that huge competitive pressures in a knowledge-based economy often drive companies to generate innovative goods by investing more in R\&D.

Investment in human capital, estimated by wage costs per employee, as an indicator of their motivation, is another essential factor. These findings, characteristic of the Romanian companies in the case study, contradict the findings of Molodchik, Shakina, and Barajas [94], in whose study, conducted in five European countries, investment in human resources, estimated by costs per employee, was an insignificant determinant of the intellectual capital.

Management team experience and training make a significant contribution to IR value. These results reinforce other findings $[98,117]$ that stress top management education and research experience as essential determinants of intangible resource worth.

The last significant factor affecting the valuation of intangible resources of the sampled companies is the degree of online penetration. As the findings of Arnott and Bridgewater's 2002 study of [118] indicate, Internet penetration represents the success of a product, helps to shape its image and enables the monitoring of the current role of business in the online environment. Our results are also correlated with the Molodchik, Shakina, and Barajas study [94], where Internet citation significantly defines reputation.

The mathematical model proposed and developed in this study, i.e., principal component analysis, provides useful and practical information for researchers, statisticians, and all managers, who will benefit from the opportunity to track the upward or downward evolution of intangible capital and to take the necessary corrective action. As all metrics can be calculated on the basis of publicly available data, this model facilitates comparative studies. It also comes as a solution to the complexities of scientific research, i.e., the study of substantial data. In addition, the proposed taxonomy of intangible resources has the capacity to facilitate the identification of this type of resource at the organizational level.

Many drawbacks have yet to be addressed. We have tried to conceptualize this model of the assessment of intangible resources using only publicly available resources, to make it a transparent tool for comparison between companies that is easy to use by all those who are interested in the activities of those companies, not just those within them. However, there are many components of intangible resources that are not transparently available to the general public and could not be included in this model. As a result, the main limitation is that we used only a limited number of IR indicators. The authors do not plan to design a standardized instrument for the calculation of IR, but rather a conceptual model that could be modified as it is actually implemented for each individual firm. 
There may be several limitations in the methods of collecting data on the companies' websites, due to the fact that the websites have not been updated or do not contain data on these factors.

Another issue is that the study was applied on a small sample, which may limit the findings. If the sample size is not large, this could have an impact on the robustness of the model. This model can be improved in future research, using a much larger sample of organizations.

Following the results of this study, it would be appropriate to continue research by identifying new financial and non-financial methods for measuring intangible resources, as management is currently facing real difficulties in measuring and evaluating this type of resource. It is desirable to identify tools to provide benchmarking opportunities related to the status of intangible resources in organizations. This will be possible through mathematical models that combine different measures of intangible resources into a single index, making it easier to apply to any organization.

New contributions are also needed to create a theoretical-conceptual and methodological framework for the management of intangible resources. For example, a future direction of research will be to develop the proposed taxonomy of intangible resources in a broader way. Finally, this paper underlines the key position of intangible resource assessments in the case of companies focused on creating sustainable value.

Author Contributions: According to their research interests and experience all authors had important contributions to the paper's conception. Conceptualization, S.S. and C.O.-S.; methodology, V.B.; software, C.O.-S.; validation, S.S. C.O.-S., and V.B.; formal analysis, V.B.; investigation, S.S.; resources, S.S.; data curation, C.O.-S.; writing - original draft preparation, S.S. and C.O.-S.; writing-review and editing, C.O.-S..; visualization, V.B.; supervision, S.S.; project administration, S.S. All authors have read and agreed to the published version of the manuscript.

Funding: This research received no external funding.

Conflicts of Interest: The authors declare no conflict of interest.

\section{References}

1. Gangi, F; Salerno, D.; Meles, A.; Daniele, L.M. Do Corporate Social Responsibility and Corporate Governance Influence Intellectual Capital Efficiency? Sustainability 2019, 11, 1899. [CrossRef]

2. Kates, R.W.; Clark, W.C.; Corell, R.; Hall, J.M.; Jaeger, C.C.; Lowe, I.; Faucheux, S. Sustainability science. Science 2001, 292, 641-642. [CrossRef] [PubMed]

3. Dresner, S. The Principles of Sustainability; Routledge: New York, NY, USA, 2012.

4. Ahi, P.; Searcy, C.; Jaber, M.Y. A quantitative approach for assessing sustainability performance of corporations. Ecol. Econ. 2018, 152, 336-346. [CrossRef]

5. Cantele, S.; Zardini, A. Is sustainability a competitive advantage for small businesses? An empirical analysis of possible mediators in the sustainability-financial performance relationship. J. Clean Prod. 2018, 182, 166-176. [CrossRef]

6. Hussain, N.; Rigoni, U.; Cavezzali, E. Does it pay to be sustainable? Looking inside the black box of the relationship between sustainability performance and financial performance. Corp. Soc. Responsib. Environ. Manag. 2018, 25, 1198-1211. [CrossRef]

7. Tseng, M.-L.; Lim, M.K.; Wu, K.-J. Corporate sustainability performance improvement using an interrelationship hierarchical model approach. Bus. Strat. Environ. 2018, 27, 1334-1346. [CrossRef]

8. Salvioni, D.M.; Gennari, F.; Bosetti, L. Sustainability and convergence: The future of corporate governance systems? Sustainability 2016, 8, 1203. [CrossRef]

9. Smigielska, G. A business case for sustainable development. Cent. Eur. Stud. Work. Pap. 2018, 10, 49-66.

10. van Marrewijk, M.; Werre, M. Multiple Levels of Corporate Sustainability. J. Bus. Ethics 2003, 44, 107-119. [CrossRef]

11. Linnenluecke, M.K.; Griffiths, A. Corporate sustainability and organizational culture. J. World Bus. 2010, 45, 357-366. [CrossRef]

12. Boros, A.; Fogarassy, C. Relationship between Corporate Sustainability and Compliance with State-Owned Enterprises in Central-Europe: A Case Study from Hungary. Sustainability 2019, 11, 5653. [CrossRef]

13. Ababneh, T.A.M.; Aga, M. The Impact of Sustainable Financial Data Governance, Political Connections, and Creative Accounting Practices on Organizational Outcomes. Sustainability 2019, 11, 5676. [CrossRef] 
14. Nielsen, J. Intangible Assets, Sustainability and Value Creation. 2018. Available online: https: //www.sustainablebusinesstoolkit.com/intangible-assets-sustainability-and-value-creation/ (accessed on 20 October 2019).

15. Clayton, T.; Radcliffe, N. Sustainability: A Systems Approach; Routledge: New York, NY, USA, 2015.

16. Drexhage, J.; Murphy, D. Sustainable development: From Brundtland to Rio 2012. Background paper prepared for consideration by the High-Level Panel on Global Sustainability at its first meeting 19 September 2010. Adv. Appl. Sociol. 2015, 5, 12.

17. Liu, J.; Mooney, H.; Hull, V.; Davis, S.J.; Gaskell, J.; Hertel, T.; Li, S. Systems integration for global sustainability. Science 2015, 347, 1258832. [CrossRef] [PubMed]

18. Rezaee, Z.; Fogarty, T. Business Sustainability, Corporate Governance, and Organizational Ethics; Wiley: Hoboken, NJ, USA, 2019.

19. Bansal, P.; DesJardine, M. Business sustainability: It is about time. Strateg. Organ. 2014, 12, 70-78. [CrossRef]

20. Gao, J.; Bansal, P. Instrumental and Integrative Logics in Business Sustainability. J. Bus. Ethics 2013, 112, 241-255. [CrossRef]

21. Hussain, T.; Edgeman, R.; Eskildsen, J.; Shoukry, A.M.; Gani, S. Sustainable enterprise excellence: Attribute-based assessment protocol. Sustainability 2018, 10, 4097. [CrossRef]

22. Phusavat, K.; Comepa, N.; Sitko-Lutek, A.; Ooi, K.-B. Interrelationships between intellectual capital and performance: Empirical examination. Ind. Manag. Data Syst. 2011, 111, 810-829. [CrossRef]

23. Voelpel, S.C.; Leibold, M.; Tekie, E.B. The wheel of business model reinvention: How to reshape your business model to leapfrog competitors. J. Change Manag. 2004, 4, 259-276. [CrossRef]

24. Bocken, N.M.; Short, S.W.; Rana, P.; Evans, S. A literature and practice review to develop sustainable business model archetypes. J. Clean. Prod. 2014, 65, 42-56. [CrossRef]

25. Vihari, N.S. Effects of business model innovation on corporate sustainability: Intervening role of organisational learning and strategic flexibility. Int. J. Innov. Learn. 2019, 26, 131-154. [CrossRef]

26. Foss, N.J.; Saebi, T. Fifteen years of research on business model innovation: How far have we come, and where should we go? J. Manag. 2017, 43, 200-227. [CrossRef]

27. Bocken, N.M. Sustainable venture capital—Catalyst for sustainable start-up success? J. Clean. Prod. 2015, 8, 647-658. [CrossRef]

28. Ritala, P.; Huotari, P.; Bocken, N.; Albareda, L.; Puumalainen, K. Sustainable business model adoption among S\&P 500 firms: A longitudinal content analysis study. J. Clean. Prod. 2018, 170, 216-226.

29. Figge, F.; Hahn, T. The cost of sustainability capital and the creation of sustainable value by companies. J. Ind. Ecol. 2005, 9, 47-58. [CrossRef]

30. Surie, G.; Ashley, A. Integrating pragmatism and ethics in entrepreneurial leadership for sustainable value creation. J. Bus. Ethics 2008, 81, 235-246. [CrossRef]

31. Vincenza, C.M.; Orlando, T. Sustainable value creation in SMEs: A case study. TQM J. 2013, 25, 44-61. [CrossRef]

32. Zbuchea, A. Are customers rewarding responsible businesses? An overview of the theory and research in the field of CSR. Manag. Dyn. Knowl. Econ. 2014, 1, 367-386.

33. Zbuchea, A.; Pînzaru, F.; Busu, M.; Stan, S.O.; Bârgăoanu, A. Sustainable Knowledge Management and Its Impact on the Performances of Biotechnology Organizations. Sustainability 2019, 11, 359. [CrossRef]

34. Cucculelli, M.; Bettinelli, C. Business models, intangibles and firm performance: Evidence on corporate entrepreneurship from Italian manufacturing SMEs. Small Bus. Econ. 2015, 45, 329-350. [CrossRef]

35. Carmeli, A. Assessing core intangible resources. Eur. Manag. J. 2004, 22, 110-122. [CrossRef]

36. Xu, J.; Wang, B. Intellectual Capital Performance of the Textile Industry in Emerging Markets: A Comparison with China and South Korea. Sustainability 2019, 11, 2354. [CrossRef]

37. Xu, J.; Wang, B. Intellectual Capital, Financial Performance and Companies' Sustainable Growth: Evidence from the Korean Manufacturing Industry. Sustainability 2018, 10, 4651. [CrossRef]

38. Canibano, L.; Garcia-Ayuso, M.; Sanchez, P. Accounting for intangibles: A literature review. J. Account. Lit. 2000, 19, 102-130.

39. Stan, S.E.; Oprean-Stan, C. Research on the Organizational Capability to Identify and Enhance Available Intangible Resources. Sciendo. In Proceedings of the International Conference Knowledge-Based Organization, Sibiu, Romania, 13-15 June 2019; Volume 25, p. 1. 
40. Stan, S.E.; Oprean-Stan, C.; Titu, M.A. New Proposal on Reporting Intangible Resources on the Organizational Level. Sciendo. In Proceedings of the International conference Knowledge-Based Organization, Sibiu, Romania, 14-16 June 2018; Volume 24, p. 1.

41. Stan, S.E.; Oprean-Stan, C.; Pele, A. A Proposal for an Intangible Resources Management System at the Organizational Level. Manag. Sustain. Dev. 2018, 10, 17-21. [CrossRef]

42. Yao, H.; Haris, M.; Tariq, G.; Javaid, H.M.; Khan, M.A.S. Intellectual Capital, Profitability, and Productivity: Evidence from Pakistani Financial Institutions. Sustainability 2019, 11, 3842. [CrossRef]

43. Ocak, M.; Findık, D. The Impact of Intangible Assets and Sub-Components of Intangible Assets on Sustainable Growth and Firm Value: Evidence from Turkish Listed Firms. Sustainability 2019, 11, 5359. [CrossRef]

44. Villalonga, B. Intangible resources, Tobin's q, and sustainability of performance differences. J. Econ. Behav. Organ. 2004, 54, 205-230. [CrossRef]

45. Goh, P.C. Intellectual capital performance of commercial banks in Malaysia. J. Intellect. Cap. 2005, 6, 385-396.

46. Holland, J. Fund management, intellectual capital, intangibles and private disclosure. Manag. Financ. 2006, 32, 277-316. [CrossRef]

47. Vidyarthi, H. Dynamics of intellectual capitals and bank efficiency in India. Serv. Ind. J. 2019, 39, 1-24. [CrossRef]

48. Surroca, J.; Tribó, J.A.; Waddock, S. Corporate responsibility and financial performance: The role of intangible resources. Strateg. Manag. J. 2010, 31, 463-490. [CrossRef]

49. Mouritzen, J. Classification, measurement and the ontology of intellectual capital entities. J. Hum. Resour. Costing Account. 2009, 13, 154-162. [CrossRef]

50. Edvinsson, L.; Malone, M. Intellectual Capital: Realizing your Company's True Value by Finding Its Hidden Brainpower; Harper Collins: New York, NY, USA, 1997.

51. Stewart, T.A. Intellectual Capital: The New Wealth of Organizations; Doubleday: New York, NY, USA, 1997.

52. Sajid, A.; Bourekkadi, S.; El Jabri, H.; Nassimi, A. Is Intangible Asset the Correct Value of the Company? A Literature Review Approach. In Vision 2020: Sustainable Economic Development and Application of Innovation Management. Available online: https://www.researchgate.net/publication/333609848_Is_ Intangible_Asset_the_Correct_Value_of_the_Company_A_Literature_Review_Approach (accessed on 3 December 2019).

53. Main, L. Assessing intangible assets and their value to business. Business E economy. Prof. Account. 2016, 28, 13-15.

54. Kaufmann, L.; Schneider, Y. Intangibles: A synthesis of current research. J. Intellect. Cap. 2004, 5, 366-388. [CrossRef]

55. Wilkinson, B. Clinical Faculty's Activities and Outputs: An Intellectual Capital Concept Map. Available online: https://tspace.library.utoronto.ca/.../Wilkinson_Belinda_L_20096_MISt_thesis.pdf (accessed on 2 November 2019).

56. Brennan, N.; Connell, B. Intellectual capital: Current issues and policy implications. J. Intellect. Cap. 2000, 7, 206-240. [CrossRef]

57. Grimaldi, M.; Corvello, V.; De Mauro, A.; Scarmozzino, E. A systematic literature review on intangible assets and open innovation. Knowl. Manag. Res. Pract. 2017, 15, 90-100. [CrossRef]

58. Kannan, G.; Aulbur, W.G. Intellectual capital: Measurement effectiveness. J. Intellect. Cap. 2004, 5, $389-413$. [CrossRef]

59. Helm, S.R. Comparison and Association of Intellectual Capital: An Investigation and Measurement of the Value of Intellectual Capital Assets and their Contribution to Stakeholder Perception within the Framework of Higher Education. Number: 3491610, ProQuest LLC; UMI Dissertation Publishing: Ann Arbor, Michigan, USA, 2012.

60. Gomez-Trujillo, A.M.; Velez-Ocampo, J.; Gonzalez-Perez, M.A. A literature review on the causality between sustainability and corporate reputation What goes first? Manag. Environ. Qual. 2020, 31, 406-430. [CrossRef]

61. Gangi, F.; Daniele, L.M.; Varrone, N. How do corporate environmental policy and corporate reputation affect risk-adjusted financial performance? Bus. Strategy Environ. 2020. [CrossRef]

62. Alon, A.; Vidovic, M. Sustainability Performance and Assurance: Influence on Reputation. Corp. Reput. Rev. 2015, 18, 337-352. [CrossRef]

63. Bezerra, M.C.D.; Gohr, C.F.; Morioka, S.N. Organizational capabilities towards corporate sustainability benefits: A systematic literature review and an integrative framework proposal. J. Clean. Prod. 2020, 247, 119114. [CrossRef] 
64. Annunziata, E.; Pucci, T.; Frey, M.; Zanni, L. The role of organizational capabilities in attaining corporate sustainability practices and economic performance: Evidence from Italian wine industry. J. Clean. Prod. 2018, 171, 1300-1311. [CrossRef]

65. Mustapha, N.A.; Hassan, R. Organizational Efficacy and Corporate Sustainability in Business Performance: A Literature Review. Adv. Sci. Lett. 2018, 24, 3493-3497. [CrossRef]

66. Appelbaum, S.H.; Calcagno, R.; Magarelli, S.M.; Saliba, M. A relationship between corporate sustainability and organizational change (part two). Ind. Commer. Train. 2016, 48, 89-96. [CrossRef]

67. Alshehhi, A.; Nobanee, H.; Khare, N. The Impact of Sustainability Practices on Corporate Financial Performance: Literature Trends and Future Research Potential. Sustainability 2018, 10, 494. [CrossRef]

68. Ameer, R.; Othman, R. Sustainability Practices and Corporate Financial Performance: A Study Based on the Top Global Corporations. J. Bus. Ethics 2012, 108, 61-79. [CrossRef]

69. Goyal, P.; Rahman, Z.; Kazmi, A.A. Corporate sustainability performance and firm performance research Literature review and future research agenda. Manag. Decis. 2013, 51, 361-379. [CrossRef]

70. Engert, S.; Rauter, R.; Baumgartner, R.J. Exploring the integration of corporate sustainability into strategic management: A literature review. J. Clean. Prod. 2016, 112, 2833-2850. [CrossRef]

71. Khan, S.Z.; Yang, Q.; Waheed, A. Investment in intangible resources and capabilities spurs sustainable competitive advantage and firm performance. Corp. Soc. Responsib. Environ. Manag. 2019, 26, 285-295. [CrossRef]

72. Ying, Q.W.; Hassan, H.; Ahmad, H. The Role of a Manager's Intangible Capabilities in Resource Acquisition and Sustainable Competitive Performance. Sustainability 2019, 11, 527. [CrossRef]

73. Corvello, V.; De Mauro, A.; Grimaldi, M.; Scarmozzino, E. The role of intangible assets in open innovation processes: A literature review. In Proceedings of the IFKAD 2015 10th International Forum on Knowledge Asset Dynamics: Culture, Innovation and Entrepreneurship: Connecting the Knowledge Dots, Bari, Italy, 10-12 June 2015; pp. 452-463.

74. Pastor, D.; Glova, J.; Liptak, F.; Kovac, V. Intangibles and methods for their valuation in financial terms: Literature review. Intang. Cap. 2017, 13, 387-410. [CrossRef]

75. WCED. Our Common Future; Oxford University Press: Oxford, UK, 1987.

76. Shrivastava, P. The role of corporations in achieving ecological sustainability. Acad. Manag. Rev. 1995, 20, 936-960. [CrossRef]

77. Carroll, A.B. Corporate social responsibility: Evolution of a definitional construct. Bus. Soc. Rev. 1999, 38, 268-295. [CrossRef]

78. Alola, U.V.; Avci, T.; Ozturen, A. Organization Sustainability through Human Resource Capital: The Impacts of Supervisor Incivility and Self-Efficacy. Sustainability 2018, 10, 2610. [CrossRef]

79. Kwantes, C.T. Culture, job satisfaction and organizational commitment in India and the United States. J. Indian Bus. Res. 2009, 1, 196-212. [CrossRef]

80. Dunphy, D.C.; Griffiths, A.; Benn, S. Organizational Change for Corporate Sustainability: A Guide for Leaders and Change Agents of the Future; Routledge: London, UK, 2003.

81. Dyllick, T.; Hockerts, K. Beyond the business case for corporate sustainability. Bus. Strategy Environ. 2002, 11, 130. [CrossRef]

82. Van Marrewijk, M. Concepts and definitions of CSR and corporate sustainability: Between agency and communion. J. Bus. Ethics 2003, 44, 95-105. [CrossRef]

83. Bansal, P. Evolving sustainably: A longitudinal study of corporate sustainable development. Strategy Manag. J. 2005, 26, 197-218. [CrossRef]

84. Bontis, N. Managing organizational knowledge by diagnosing intellectual capital: Framing and advancing the state of the field. Int. J. Technol. Manag. 1999, 18, 433-462. [CrossRef]

85. Bontis, N. Assesing Knowledge Assets - A Review of the Models Used to Measure Intellectual Capital. Int. J. Manag. Rev. 2001, 3, 41-60. [CrossRef]

86. Van Buren, M.E. A yardstick for knowledge management. Train. Dev. 1999, 53, 71.

87. Dzinkowski, R. The measurement and management of intellectual capital: An introduction. Manag. Account. 2000, 78, 32-36.

88. Roos, J.; Roos, G.; Dragonetti, N.C.; Edvinsson, L. Intellectual capital: Navigating in the New Business Landscape; Macmilan: Basingstoke, UK, 1997. 
89. Saint-Onge, H. Tacit knowledge: The key to the strategic alignment of intellectual Capital. Strategy Leadersh. 1996, 24, 10-14. [CrossRef]

90. Kong, E. The strategic importance of intellectual capital in non-profit sector. J. Intellect. Cap. 2007, 5, 721-731. [CrossRef]

91. Grasenick, K.; Low, J. Shaken, not stirred: Defining and connecting indicators for the measurement and valuation of intangibles. J. Intellect. Cap. 2004, 5, 268-281. [CrossRef]

92. Fletcher, A.; Guthrie, J.; Steane, P.; Roos, G.; Pike, S. Mapping stakeholder perceptions for a third sector organization. J. Intellect. Cap. 2003, 4, 505-527. [CrossRef]

93. Stan, S. Intangible resources-New creative engines for welfare in organizations. Strateg. Manag. 2017, 1,763-771.

94. Molodchik, M.A.; Shakina, E.A.; Barajas, A. Metrics for the elements of intellectual capital in an economy driven by knowledge. J. Intellect. Cap. 2014, 15, 206-226. [CrossRef]

95. InCaS. Intellectual Capital Statement, Made in Europe. 2009. Available online: https://cordis.europa.eu/docs/ results/30/30485/123971741-6_en.pdf (accessed on 1 December 2019).

96. Brătianu, C. Capitalul Intelectual Organizational; ASE, Bucharest: Bucharest, Romania, 2009.

97. Porter, M. Competitive advantage, agglomeration economies, and regional policy. Int. Reg. Sci. Rev. 1996, 19, 49-77. [CrossRef]

98. Tseng, C.-Y.; Goo, Y.-J.J. Intellectual capital and corporate value in an emerging economy: Empirical study of Taiwanese manufacturers. $R$ D Manag. 2005, 35, 187-201. [CrossRef]

99. www.oceantomo.com. Available online: www.oceantomo.com/blog/2015/03-05-ocean-tomo-2015-intangibleasset-market-value/ (accessed on 15 October 2019).

100. Sveiby, K.E. The Intangible Assets Monitor. J. Hum. Resour. Costing Account. 1997, 2, 73-97. [CrossRef]

101. Jacobsen, K.; Hofman-Bang, P.; Reidar, J. The IC Rating ${ }^{\mathrm{TM}}$ model by Intellectual Capital Sweden. J. Intellect. Cap. 2005, 6, 570-587. [CrossRef]

102. Petty, R.; Guthrie, J. Intellectual capital literature review: Measurement, reporting and management. J. Intellect. Cap. 2000, 1, 155-176. [CrossRef]

103. Williams, M. Is a company's intellectual capital performance and intellectual capital disclosure practices related? Evidence from publicly listed companies from the FTSE 100, 2000, Paper presented at: Mc Masters Intellectual Capital Conference, January 2001, Hamilton, Ontario, Canada. Available online: https://vuthedudotorg.files.wordpress.com/2015/04/intellectual-capital-performance3.pdf (accessed on 19 November 2019).

104. Andriessen, D. IC valuation and measurement: Classifying the state of the art. J. Intellect. Cap. 2004, 5, 230-242. [CrossRef]

105. Tan, H.P.; Plowman, D.; Hancock, P. The evolving research on intellectual capital. J. Intellect. Cap. 2008, 9, 585-608. [CrossRef]

106. Jurczak, J. Intellectual Capital Measurement Methods. Economics and Organization of Enterprise 2008, 1, 37-45. [CrossRef]

107. Ku, L. The Importance of Corporate Sustainability. Available online: https://www.plugandplaytechcenter. com/resources/corporate-sustainability/ (accessed on 20 October 2019).

108. Kucharcikova, A.; Miciak, M.; Hitka, M. Evaluating the Effectiveness of Investment in Human Capital in E-Business Enterprise in the Context of Sustainability. Sustainability 2018, 10, 3211. [CrossRef]

109. Pike, S.; Roos, G.; Marr, B. Strategic management of intangible assets and value drivers in R\&D organizations. R D Manag. 2005, 32, 111-124.

110. Tseng, C.-Y. Internal R\&D effort, external imported technology and economic value added: Empirical study of Taiwan's electronic industry. Appl. Econ. 2008, 40, 1073-1082.

111. Roos, G.; Pike, S.; Fernstrom, L. Managing Intellectual Capital in Practice; Elsevier: Burlington, MA, USA; Butterworth-Heinemann: Oxford, UK, 2005.

112. Kipnis, E. Branding beyond prejudice: Navigating multicultural marketplaces for consumer well-being. J. Bus. Res. 2013, 66, 1186-1194. [CrossRef]

113. Jardon, C.; Martos, M.S. Intellectual capital as competitive advantage in emerging clusters in Latin America. J. Intellect. Cap. 2012, 13, 462-481. [CrossRef]

114. Pulic, A. VAIC-An accounting tool for IC management. International J. Technol. Manag. 2000, 20, 702-714. [CrossRef] 
115. Rompho, B.; Siengthai, S. Integrated performance measurement system for firm's human capital building. J. Intellect. Cap. 2012, 13, 482-514. [CrossRef]

116. Mondy, W.; Noe, R. Human Resource Management, 10th ed.; Prentice Hall: Upper Saddle River, NJ, USA, 2008.

117. Ugboro, I.O.; Obeng, K. Top management leadership, employee empowerment, job satisfaction, and customer satisfaction in TQM organizations: An empirical study. J. Qual. Manag. 2000, 5, 247-272. [CrossRef]

118. Arnott, D.C.; Bridgewater, S. Internet, interaction and implication for marketing. Mark. Intell. Plan. 2002, 20, 86-95. [CrossRef]

119. Hakansson, H.; Snekota, I. Developing Relationships in Business Networks; Routledge: London, UK, 1995.

120. Romero, D.; Molina, A. Collaborative networked organizations and customer communities: Value co-creation and co-innovation in the networking era. Prod. Plan. Control 2010, 22, 447-472. [CrossRef]

121. Sydler, R.; Haefliger, S.; Pruksa, R. Measuring intellectual capital with financial figures: Can we predict firm profitability? Eur. Manag. J. 2014, 32, 244-259. [CrossRef]

122. Indices profile of Bucharest Stock Exchange. Available online: http://www.bvb.ro/FinancialInstruments/ Indices/IndicesProfiles (accessed on 10 November 2018).

123. Page Rank checker service. Available online: https://www.prchecker.info/check_page_rank.php (accessed on 21 December 2019).

124. Bucur, A. Contribuţii la Abordarea Ştiinţifică a Calităţii şi Managementului Calităţii, Prin Modelare şi Simulare; University of Sibiu Publishing House: Sibiu, Romania, 2015; pp. 57-70.

125. Chih-Fong, T.; Yu-Hsin, L.; David, C.Y. Determinants of intangible assets value: The data mining approach. Knowl. -Based Syst. 2012, 31, 67-77. [CrossRef]

126. Fukui, Y.; Ushijima, T. Corporate diversification, performance, and restructuring in the largest Japanese manufacturers. J. Jpn. Int. Econ. 2007, 21, 303-323. [CrossRef]

127. Gleason, K.I.; Klock, M. Intangible capital in the pharmaceutical and chemical industry. Q. Rev. Econ. Financ. 2006, 46, 300-314. [CrossRef]

(C) 2020 by the authors. Licensee MDPI, Basel, Switzerland. This article is an open access article distributed under the terms and conditions of the Creative Commons Attribution (CC BY) license (http://creativecommons.org/licenses/by/4.0/). 